\title{
UTILIZATION OF SPENT COFFEE GROUNDS FOR REMOVAL OF HAZARDOUS SUBSTANCES FROM WATER: A REVIEW
}

\author{
Lenka BLINOVÁ ${ }^{1}$, Maroš SIROTIAK ${ }^{1}$ \\ ${ }^{1}$ SLOVAK UNIVERSITY OF TECHNOLOGY IN BRATISLAVA, \\ FACULTY OF MATERIALS SCIENCE AND TECHNOLOGY IN TRNAVA, \\ INSTITUTE OF INTEGRATED SAFETY \\ ULICA JÁNA BOTTU 2781/25, 91724 TRNAVA, SLOVAK REPUBLIC \\ e-mail: lenka.blinova@stuba.sk,maros.sirotiak@stuba.sk \\ Received: 15.05.2019, Accepted: 20.06.2019, Published: 25.07.2019
}

\begin{abstract}
Water is one of the most important substances on earth; nowadays, its pollution is one of the main environmental problems. Textile industries pose a significant environmental problem for earth. Firstly, it is due to their huge water consumption, and secondly, they produce a lot of wastewater contaminated with dyes, chemicals, suspended solids, etc. These contaminants can make water unsuitable for the desired purposes (e.g., drinking, watering, washing and showering). The one of the promising methods for the removal of dyes from the contaminated wastewater is adsorption. In this process, we can use low cost waste materials as an adsorbent. This paper presents an overview of utilization of the spent coffee grounds for the removal of dyes from wastewater.
\end{abstract}

\section{Key words}

Waste utilization, spent coffee grounds, adsorption, dye removal, water treatment

\section{INTRODUCTION}

About two-thirds of the Earth's surface is covered with water, yet there is a scarcity of drinkable water around us. The rivers, lakes, seas and oceans are drowned in chemicals, waste, plastics and other pollutants. These harmful substances degrade water quality and render it toxic to humans or the environment $[1,2]$.

The wastewater from textile plants is considered as the most polluting of all the industrial sectors when considering the effluent composition as well as the volume produced. Nowadays, dye wastewater is becoming one of the substantial sources of severe pollution problems. The main reason is fast fashion (increased demand for textile products means the proportional increase in their production linked with use of synthetic dyes) [3]. 
The toxicity and health risks of most of these pollutants are well-understood, and their presence in drinking water above a certain limit can pose serious health risks to the human body and animals. Practically all types of water pollution can be harmful to our health after long term exposure, but they also may damage our health after immediate exposure. We need clean water without contaminant to survive. This is the main reason why the removal of pollutants from water is so important for people [4].

\section{CHEMICALS USED IN TEXTILE INDUSTRY}

Textile industry requires a wide range of operations, from cleaning natural fibres and smoothing agents to improving easy care properties. For these operations, a lot of chemicals in all parts of textile processing are used [3]. The processing includes:

- Fibre production (pesticides, insecticides, fertilisers, scouring chemicals, acids, bases, process chemicals, petroleum-based feedstock, dyes, pigments, catalysts, stabilizers),

- Yarn production (spinning oils),

- Fabric production (weaving: sizing chemicals, knitting: lubricants, non-woven: solvents, adhesives, binders),

- Pre-treatment (washing, general cleaning of the fabric following previous steps and treatments: detergents, solvents; de-sizing removes the sizing chemicals from the warp yarns in the woven fabric: enzymes; scouring removes fatty waxes and greases from natural fibres, cotton seed and husk: detergents, bases, solvents; bleaching makes the fibres whiter and facilitates the dyeing process, it also makes the fibres more absorbent: bleaches; mercerizing makes cellulosic fibres swell and get stronger, more lustrous and a greater capacity to accept dye - by doing so one can reduce the amount of dyes needed: bases; carbonizing removes vegetable residues such as seed pods from the wool: acids),

- Dyeing and printing (dyeing: pigments, dyes, metals as metal complex dye - lead, cobalt, chromium, copper; printing: pigments, dyes, plasticisers, binders and polymeric resin such as acrylates, PVC, PUR; washing: detergents),

- Finishing treatments (handle modification: softeners such as polyethylene, quaternary ammonium compounds, silicones, polyurethanes and stiffeners such as starches resins, polyvinylacetat, polyvinylalcohol; crease resistance (anti-wrinkling, easy care): different types of resins, often formaldehyde based); antistatic treatment: cationic softeners, polyglycols; anti-pilling: resins; antibacterial/anti-odor treatment: nanoparticles of silver, titanium oxide and zinc oxide, triclosane; water resistant: water repellents based on waxes, silicones, fluorocarbons; oil/soil resistant: oil/soil repellents based on fluorocarbons; flame retardancy: flame retardants - halogenated, phosphor based; protective coatings: acrylates, polyurethanes, silicones, PVC with plasticisers; laminated films and membranes: in the material layers - different types of polymers such as polyurethane, polytetrafluorethylene, modified polyester, in adhesives - different types of polymers such as polyurethane based, and thermoplastic polymers; garment treatments for fashion: potassium permanganate, sodium hypochlorite, calcium hypochlorite, sodium hydro sulphite, potassium dichromate, formaldehyde resins, cationic softeners, cationic silicone softeners),

- Garment making, transport, sales and retail (transport preparation, which includes protection from mould during transportation and storage, mostly using biocides: dimethyl fumarate, ethylene oxide, methylbromide, 1,2 dichloroethane, phosphine, dichloromethane, sulfuryl fluoride) [5-8].

The scheme of textile industry process and its environmental effects is shown in Fig. 1. 

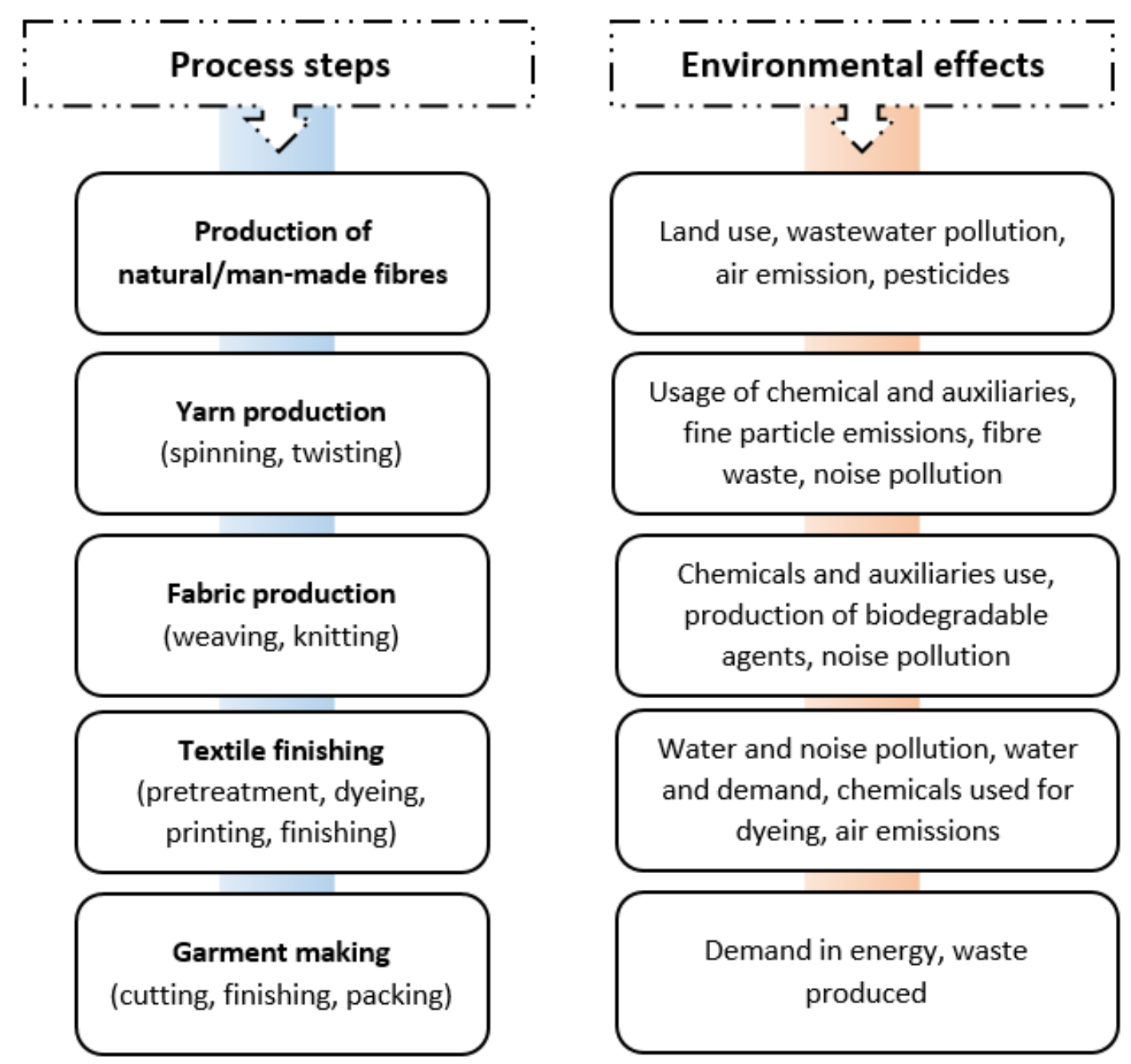

Fig. 1 Scheme of textile industry process and its environmental effects [9]

Dyes are one of the most relevant environmental pollutants present in large amount in the wastewater not only from textile industry but also from plastic factories, tannery, cosmetic and pharmaceutical industry, food industry and photographic and paper industries $[5,7,10]$.

Dyes may be defined as substances that, when applied to a substrate, provide colour by a process that alters, at least temporarily, any crystal structure of the coloured substances. Dyes are classified according to their application and chemical structure (acid, basic, direct, mordant, vat, reactive, disperse, azo and sulphur dyes [5]), and are composed of a group of atoms known as chromophores, responsible for the dye colour. These chromophore containing centres are based on diverse functional groups, such as azo, anthraquinone, methine, nitro, arylmethane, and carbonyl. In addition, electrons withdrawing or donating substituents so as to generate or intensify the colour of the chromophores are denominated as auxochromes (e.g., amine, carboxyl, sulfonate and hydroxyl) [7].

The textile dyes contain various chemicals. [5, 8] It is estimated that over 100,000 different dyes and pigments are used industrially [11]. In the textile industry, up to 200,000 tons of these dyes are lost to effluents every year during the dyeing and finishing operations, due to the inefficiency of the dyeing process. Unfortunately, most of these dyes escape conventional wastewater treatment processes and persist in the environment as a result of their high stability to light, temperature, water, detergents, chemicals, soap and other parameters [7]. 


\section{ADSORPTION AS PROCESS FOR REMOVAL OF DYES}

The most common methods of the dyes removal from wastewaters include e.g., chemical precipitation, ultrafiltration [12], aerobic and anaerobic biological treatment [13], chemical coagulation/flocculation [14], advanced oxidation processes [15], electrochemical treatments [16], and reverse osmosis [17]. However, some of these processes are expensive and ineffective to treat huge range of wastewater [18].

Another method which is a promising alternative for removing dyes from aqueous media is adsorption, which is due to its efficiency, high selectivity, low cost, ease of operation, simplicity and availability in a wide range of experimental conditions $[5,10]$. The current aim is find an efficient low cost adsorbent. The utilization of waste to treat wastewater can not only solve environmental issue with inexpensive cost, but also reduce the waste in landfill, as the waste can be reused. From an economical point of view, a low cost sorbent is known as a sorbent that is abundant in nature and can be easily available, or is a by-product or waste from industry, is of little or no economic value, and requires little or no processing [19]. All advantages of adsorption are closely related to the conditions of the adsorption [10]. There are a lot more factors that can influence adsorption process, however, solution $\mathrm{pH}$ type of adsorbent, contact time, adsorbent concentration, dose of adsorbent, initial dye concentration and temperature are the main of them [18].

Adsorption techniques using solid adsorbents (e.g., the activated alumina, the silica gel, zeolites, activated carbon) are well established for treating industrial wastewater $[5,20]$. The most commonly used adsorbent for treatment of water pollutant such as dye is activated carbon (also known as solid sponge) i.e. a carbon form using either physical or chemical treatment. Treating wastewater by using conventional activated carbon that is available in the market is expensive and its regeneration is even costly [18]. Activated carbon can be manufactured from a large variety of raw materials, basically by two methods, physical and chemical activation, or combination of both [21]. In the recent period, adsorption processes that use magnetic nanoparticles show a high efficiency in removing dyes from aqueous effluents [10]. Adsorbents produced from agricultural waste are cheap and can be divided onto two groups: (1) activated carbon and (2) solid waste from raw agricultural waste and material waste from forest industries. There are a lot of studies conducted on the raw and activated carbon agricultural waste such as sugarcane bagasse, olive stone, apple waste, macadamia shell, bamboo, corncob, coffee residue, pomegranate peel, coconut shell, rice husk, straw, coir pith, orange peel, banana peel, durian peel, pomelo peel, broad bean peel, almond shell, peanut hull, pineapple stem etc. $[18,22,23]$. Adsorbents produced from industrial waste can be also divided onto two groups (1) activated carbon from solid waste (e.g., sewage sludge) and (2) by-product (e.g., fly ash, red mud, ceramic adsorbents prepared from industrial waste coal gangue, industrial microbial waste). Sewage sludge as adsorbent can be produced using different activation process to adsorb metals and dye from wastewater. Some industrial by-product such as fly ash is used in many countries even though it may contain some hazardous substance, because it is an abundant and easily available material $[18,24,25]$. Biosorbent or a sea material (e.g., chitosan, algae and seafood waste - conch shells, mussel shells) can be also used as a sorbent to treat wastewater $[11,18]$.

\section{SPENT COFFEE GROUNDS AS A SORBENT}

Coffee is one of the most important agricultural commodities in the world [26]. Total production of coffee by all exporting countries in thousand $60 \mathrm{~kg}$ bags in 2018 was 169063 [27]. 
Coffee production generates a lot of by-products (e.g., spent coffee ground, coffee fruit coffee cherry, coffee husks, peel, pulp, minor wastes: defective green coffee beans, coffee tree leaves during harvest) worldwide [5, 26]. During the extraction of the beverage from coffee powder with hot water, a large amount of residue, such as spent coffee grounds (SCG), is produced, and considering the worldwide coffee consumption, it can be concluded that tons of coffee waste are generated from cafeterias and domestic production [5, 28]. Some of byproducts or residue can be used for different application. For the removal of dyes from aqueous solutions, coffee cherry husks and spent coffee grounds can be used [26, 29].

SCG are the most abundant coffee by-product generated not only in the coffee beverage preparation but also during the instant coffee manufacturing (almost 50\% of the worldwide coffee production is processed for soluble coffee preparation). Coffee brews are usually prepared with an Arabica coffee or Arabica/Robusta blends, of a single or different geographical origins, being available to consumers as roasted beans, whole or ground, or even as instant/soluble coffee. Thus, the "spent coffee grounds" terminology includes those obtained from the soluble coffee industry, as well as those produced after brewing at cafeterias or at home. Numerically, 1 ton of green coffee generates about $650 \mathrm{~kg}$ of SCG, and about $0.91 \mathrm{~g}$ spent coffee grounds are produced per $1 \mathrm{~g}$ of ground coffee, and about 2 kilograms of wet spent coffee grounds are produced for every kilogram of instant coffee made [5, 26, 28].

Chemical composition of coffee brews is dependent on the extractive efficiency, which relies on diverse factors, including the coffee species, roasting degree, grinding grade, coffee/water ratio, water quality, temperature, pressure and percolation time. Therefore, different extraction processes will lead to sensorial and chemically distinct brews and, thus, distinct SCG. In fact, industrially spent coffee constituents are much more effectively extracted, thus resulting in more chemically exhausted remains, in comparison to the spent coffee obtained after brewing from the cafeterias/household environments. SCG are composed of $12.4 \%$ cellulose, $39.1 \%$ hemicellulose (3.60\% arabinose, $19.07 \%$ mannose, $16.43 \%$ galactose), $23.90 \%$ lignin, $2.29 \%$ fat, $17.44 \%$ protein, and $60.46 \%$ total dietary fibre. It makes them an interesting source of raw materials for different applications. The differences in chemical composition of SCG presented in other papers probably reflect the variety of beans and processes used in roasting and extraction [26].

SCG can be used as an adsorbent for dye removal by direct use, or after their treatment. [30] Maximum adsorption capacity (MAC) or maximum efficiency of colour removal (ME) depends on various conditions during the sorption process, such as type of dye, initial dye concentration, $\mathrm{pH}$ solution, dosage of adsorbent, contact time and temperature of solution.

As can be seen in Table 1, MAC really depends on the type of adsorbent because e.g., the range of MAC for methylene blue is from $23.40 \mathrm{mg} \mathrm{g}^{-1}$ (used SCG without treatment) to $986.80 \mathrm{mg} \mathrm{g}^{-1}$ (used activated carbon from SCG). To achieve the highest MAC or ME, we have to find the best conditions of the sorption process for every type of dye. 


\begin{tabular}{|c|c|c|c|}
\hline Adsorbent & Dye & $\begin{array}{l}\text { Maximum adsorption } \\
\text { capacity }\left[\mathrm{mg} \mathrm{g}^{-1}\right]\end{array}$ & Source \\
\hline \multirow{5}{*}{ SCG } & Neutral Red & 136.98 & [31] \\
\hline & Acid Dye 44 & 27.80 & [32] \\
\hline & Methylene Blue & 23.40 & [33] \\
\hline & Rhodamine $6 \mathrm{G}$ & 8.08 & \multirow{2}{*}[34]{} \\
\hline & Rhodamine B & 2.52 & \\
\hline \multirow{2}{*}{$\begin{array}{l}\text { SCG from } \\
\text { "Greek Coffee }\end{array}$} & $\begin{array}{l}\text { Real textile wastewaters contains } \\
\text { Remazol Red 3BS, Remazol }\end{array}$ & $241.00(\mathrm{pH}=2)$ & \multirow{2}{*}[35]{} \\
\hline & $\begin{array}{l}\text { Yellow gelb 3RS, Remazol Blue } \\
\text { RN }\end{array}$ & $179.00(\mathrm{pH}=10)$ & \\
\hline \multirow{8}{*}{ Magnetic SCG } & Methylene Blue & 78.10 & [36] \\
\hline & Acridine Orange & 73.40 & \multirow{7}{*}{ [29] } \\
\hline & Bismarck Brown Y & 69.20 & \\
\hline & Crystal Violet & 68.10 & \\
\hline & Safranin $\mathrm{O}$ & 59.00 & \\
\hline & Malachite Green & 43.00 & \\
\hline & Congo Red & 9.43 & \\
\hline & Amido Black 10B & 1.24 & \\
\hline \multirow{3}{*}{$\begin{array}{l}\text { Activated } \\
\text { carbon from } \\
\text { SCG }\end{array}$} & Methylene Blue & 986.80 & \multirow{2}{*}[37]{} \\
\hline & Acid Orange 7 & 665.90 & \\
\hline & Methyl Orange & 658.00 & {$[38]$} \\
\hline Sulfonated SCG & Methylene Blue & 812.00 & {$[30]$} \\
\hline
\end{tabular}

\section{CONCLUSION}

With over 2.25 billion cups of coffee consumed worldwide on daily basis, coffee is the second most traded commodity in the world. We can imagine how much spent coffee grounds are produced every day. Nowadays, this type of waste is underutilized in large amounts ending in landfills. This waste is a low cost material which can be used for different applications (e.g., production of fuel pellets, as a source of sugars, composting material or a substrate for mushroom production). One of the potential uses of SCG is its application as a sorbent for removal of metal ions and dye from wastewater.

There is no dye dyeing all the existing fibres, and no fibre which can be dyed by all known dyes. Therefore, it is not possible to use one type of dye for dyeing wool, polyester, cotton etc. We must use a lot of types of dyes, and thus produce wastewater with many kinds of contaminants. Synthetic dyes are one of the most hazardous organic pollutants in industrial effluents. They raise serious of environmental issues due to their high biotoxicity and carcinogenic effects.

There is an urgent need for practical and innovative ideas of utilization of any materials for treatment of wastewater. We need to stop contaminating the water resources, because water is our life. If the water contains contaminants, it is unhealthy for us. There are a lot of studies focused on the removal of dye from wastewater using low cost materials, such as SCG. The important thing now is to ensure that the adsorbent can be used effectively in the industrial scale. Further investigations on the development of adsorption process for real conditions of wastewater need to be conducted, as the industrial effluents contains several pollutants simultaneously. 


\section{References}

[1] DENCHAK, M. 2018. Water Pollution: Everything You Need to Know. [Online]. [Accessed: 052019] Available at https://www.nrdc.org/stories/water-pollution-everything-you-need-know.

[2] CHRIS, W. 2019. Water pollution: an introduction. [Online]. [Accessed: 04-2019] Available at https://www.explainthatstuff.com/waterpollution.html.

[3] www.pure-chemical.com, 2015, Chemicals in Textile Industry [Online]. [Accessed: 04-2019] Available at https://www.pure-chemical.com/blog/chemicals-in-textile-industry/.

[4] SAJID, M. et al. 2018. Removal of heavy metals and organic pollutants from water using dendritic polymers based adsorbents: A critical review. Separation and Purification Technology, 191, 400423. ISSN 1383-5866.

[5] ANASTOPOULOS, I. et al. 2017. A review for coffee adsorbents. Journal of Molecular Liquids, 229, 555-565. ISSN 0167-7322.

[6] www.textileguide.chemsec.org, The textile process [Online]. [Accessed: 05-2019] Available at http://textileguide.chemsec.org/find/get-familiar-with-your-textile-production-processes/.

[7] CHEQUER, F. M. D. et al. 2013. Textile Dyes: Dyeing Process and Environmental Impact, EcoFriendly Textile Dyeing and Finishing, Melih Günay, IntechOpen, DOI: 10.5772/53659. Available at https://www.intechopen.com/books/eco-friendly-textile-dyeing-and-finishing/textile-dyesdyeing-process-and-environmental-impact.

[8] ROVIRA, J., DOMINGO, J. L. 2019. Human health risks due to exposure to inorganic and organic chemicals from textiles: A review. Environmental Research, 168, 62-69. ISSN 0013-9351.

[9] KUMAR, P. S., PAVITHRA, K. G. 2019. Water and textiles. In: MUTHU, S. S., editors. Water in Textiles and Fashion. $1^{\text {st }}$ edition. Woodhead Publishing, 2019. Chapter 2. ISBN 978-0-08102633-5. Available at https://www.sciencedirect.com/topics/engineering/textilewastewater.

[10] BULGARIU, L. et al. 2019. The utilization of leaf-based adsorbents for dyes removal: A review. Journal of Molecular Liquids, 276, 728-747. ISSN 0167-7322.

[11] EL OUAHABI, I. et al. 2018. Adsorption of textile dye from aqueous solution onto a low cost conch shells. Journal of Materials and Environmental Sciences, 9(7), 1987-1998. ISSN 2028-2508.

[12] TANG, L. et al. 2019. Removal of active dyes by ultrafiltration membrane pre-deposited with a PSFM coagulant: Performance and mechanism. Chemosphere, 223, 204-210. ISSN 0045-6535.

[13] SHOUKAT, R. et al. 2019. Hybrid anaerobic-aerobic biological treatment for real textile wastewater. Journal of Water Process Engineering, 29, 100804. ISSN 2214-7144.

[14] DOTTO, J. et al. 2019. Performance of different coagulants in the coagulation/flocculation process of textile wastewater. Journal of Cleaner Production, 208, 656-665. ISSN 0959-6526.

[15] ZOU, H. et al. 2019. The agricultural use potential of the detoxified textile dyeing sludge by integrated Ultrasound/Fenton-like process: A comparative study. Ecotoxicology and Environmental Safety, 172, 26-32. ISSN 0147-6513.

[16] NÚÑEZ, J. et al. 2019. Application of electrocoagulation for the efficient pollutants removal to reuse the treated wastewater in the dyeing process of the textile industry. Journal of Hazardous Materials, 371, 705-711. ISSN 0304-3894.

[17] CINPERI, N. C. et al. Treatment of woolen textile wastewater using membrane bioreactor, nanofiltration and reverse osmosis for reuse in production processes. Journal of Cleaner Production, 223, 837-848, ISSN 0959-6526.

[18] RAZI, M. A. M. et al. 2017. Factor Affecting Textile Dye Removal Using Adsorbent From Activated Carbon: A Review. In: International Symposium on Civil and Environmental Engineering 2016. MATEC Web of Conferences, 103, 06015 (2017). ISSN 2261-236X.

[19] SULYMAN, M. et al. 2017. Low-cost adsorbents derived from agricultural by-products/wastes for enhancing contaminant uptakes from wastewater: A review. Polish Journal of Environmental Studies, 26(2), 479-510, ISSN: 1230-1485.

[20] WANG, C. et al. 2009. Adsorption of Dye from Wastewater by Zeolites Synthesized from Fly Ash: Kinetic and Equilibrium Studies. Chinese Journal of Chemical Engineering, 17(3), 513-521. ISSN 1004-954. 
[21] YEGANEH, M. M. et al. 2006. Effect of raw materials on properties of activated carbons. Chemical Engineering Technology, 29(10), 1247-1251. ISSN 1521-4125.

[22] HAMEED, B. H. et al. 2009. A novel agricultural waste adsorbent for the removal of cationic dye from aqueous solutions. Journal of Hazardous Materials, 162(1), 305-311. ISSN 0304-3894.

[23] BHARATHI, K. S., RAMESH, S. T. 2013. Removal of dyes using agricultural waste as low-cost adsorbents: a review. Applied Water Science, 3, 773-790. ISSN 2190-5495.

[24] ZHOU, L. et al. 2019. Adsorption removal of cationic dyes from aqueous solutions using ceramic adsorbents prepared from industrial waste coal gangue. Journal of Environmental Management, 234, 245-252. ISSN 0301-4797.

[25] LIU, J. et al. 2019. Characterization and utilization of industrial microbial waste as novel adsorbent to remove single and mixed dyes from water. Journal of Cleaner Production, 208, 552-562. ISSN 0959-6526.

[26] BLINOVÁ, L. et al. 2017. Review: Utilization of Waste From Coffee Production. Research Papers Faculty of Materials Science and Technology Slovak University of Technology, 25(40), 91-101. ISSN 1338-0532.

[27] www.ico.org, Total production by all exporting countries [Online]. [Accessed: 04-2019] Available at http://www.ico.org/prices/po-production.pdf.

[28] BLINOVÁ, L. et al. 2017. Biodiesel production from spent coffee grounds. Research Papers Faculty of Materials Science and Technology Slovak University of Technology, 25(40), 113-122. ISSN 1338-0532.

[29] SAFARIK, I. et al. 2011. Magnetically modified spent coffee grounds for dyes removal. European Food Research and Technology, 234(2), 345-350. ISSN 1438-2385.

[30] LOPEZ, J. et al. 2018. Green synthesis of a highly efficient biosorbent for organic, pharmaceutical, and heavy metal pollutants removal: Engineering surface chemistry of polymeric biomass of spent coffee waste. Journal of Water Process Engineering, 25, 309-319. ISSN 2214-7144.

[31] McNUTT, J., HE, Q. S. 2019. Spent coffee grounds: A review on current utilization. Journal of Industrial and Engineering Chemistry, 71, 78-88. ISSN 1226-086X.

[32] ROH, J. et al. 2012. Waste coffee-grounds as potential biosorbents for removal of acid dye 44 from aqueous solution. Korean Journal of Chemical Engineering, 29(7), 903-907. ISSN 1975-7220.

[33] FRANCA, A. S. et al. 2009. Kinetics and equilibrium studies of methylene blue adsorption by spent coffee grounds. Desalination, 249(1), 267-272. ISSN 0011-9164.

[34] SHEN, K., GONDAL, M. A. 2017. Removal of hazardous Rhodamine dye from water by adsorption onto exhausted coffee ground. Journal of Saudi Chemical Society, 21(1), S120-S127. ISSN 1319-6103.

[35] KYZAS, G. Z. 2012. A decolorization technique with spent "Greek coffee" grounds as zero-cost adsorbents for industrial textile wastewaters. Materials (Basel), 5(11), 2069-2087.

[36] ZUORRO, A. et al. 2014. Magnetically Modified Agro-Industrial Wastes as Efficient and Easily Recoverable Adsorbents for Water Treatment. Chemical Engineering Transactions, 38, 349-354. ISSN 2283-9216.

[37] JUNG, K. W. et al. 2016. Fabrication of granular activated carbons derived from spent coffee grounds by entrapment in calcium alginate beads for adsorption of acid orange 7 and methylene blue. Bioresource Technology, 219, 185-195. ISSN 0960-8524.

[38] RATTANAPAN, S. et al. 2017. Adsorption of Methyl Orange on Coffee grounds Activated Carbon. Energy Procedia, 138, 949-954. ISSN 1876-6102.

\section{ORCID}

Lenka Blinová

Maroš Sirotiak
0000-0001-6971-6558

0000-0003-1487-801X 